\title{
PENGGUNAAN METODE BLENDED LEARNING BERBASIS EDMODO UNTUK MENINGKATKATKAN HASIL BELAJAR SISWA KELAS VII PADA MATERI PENCEMARAN UDARA DI SMPN 02 SUMBERBARU
}

\author{
${ }^{1}$ Siti Kartinawati, ${ }^{2}$ Diah Sudiarti, ${ }^{3}$ Umi Nurjanah \\ ${ }_{123}$ Pendidikan Biologi, Universitas Islam Jember \\ 1Skartinawati@gmail.com, ${ }^{2}$ diah.sudiarti23@gmail.com, ${ }^{3}$ kholidumi@gmail.com
}

\begin{abstract}
ABSTRAK
Penelitian ini bertujuan untuk meningkatkan hasil belajar siswa melalui metode blended learning berbasis edmodo. Jenis penelitian yang digunakan adalah penelitian tindakan kelas (PTK) dengan menggunakan II siklus. Berdasarkan hasil penelitian, persentase ketuntasan hasil belajar siswa pada siklus I diperoleh nilai sebesar 57,14\%. Sedangkan persentase ketuntasan hasil belajar siswa pada siklus II diperoleh nilai sebesar 85,71\%..Dengan demikian terdapat peningkatan nilai ketuntasan hasil belajar pada siklus I dan siklus II. Dari perolehan rata-rata tersebut dapat dinyatakan bahwa kegiatan belajar mengajar menggunakan metode blended learning berbasis edmodo mengalami peningkatan yang cukup baik..
\end{abstract}

Kata kunci: Blended Learning, Edmodo, Hasil Belajar Siswa.

\section{ABSTRACT}

This study aims to improve student learning outcomes through edmodo-based blended learning methods. This type of research is a classroom action research (CAR) using II cycle. Based on the results of the study, the percentage of completeness of student learning outcomes in the first cycle obtained a value of $57.14 \%$. While the percentage of completeness of student learning outcomes in the second cycle obtained a value of $85.71 \%$. Thus there is an increase in the value of completeness of learning outcomes in the first cycle and second cycle. From the average acquisition it can be stated that teaching and learning activities using edmodo-based blended learning methods have increased quite well.

Key words: Blended Learning, Edmodo, Student Learning Outcomes

\section{PENDAHULUAN}

Secara historis, para pendidik telah memikirkan pola pembelajaran yang di laksanakan secara tatap muka dengan mediasi komputer, atau pembelajaran yang terdiri dari sebuah kombinasi tatap muka dan format pembelajaran yang dilakukan dengan menggunakan perangkat komputer yang disebut dengan blended learning (Graham, 2006). Blended learning mengandung arti percampuran atau kombinasi pembelajaran atau perpaduan dari unsur-unsur pembelajaran tatap muka langsung dan online secara harmonis dan perpaduan yang ideal (Heinze, 2006).

Metode Blended learning merupakan pembelajaran yang mengombinasi atau mencampur antara pembelajaran tatap muka (face-to-face) dan pembelajaran berbasis komputer (online dan offline), (Dwiyogo, 2011).

Salah satunya dengan menggunakan aplikasi edmodo yang di dalamnya terdapat berbagai konten untuk pendidikan. Edmodo merupakan sebuah Learning Managenent System (LSM) yang menyediakan beragam fitur yang bisa 
dimanfaatkan oleh guru untuk kegiatan pembelajaran. Edmodo memiliki tiga fungsi dalam proses pembelajaran, yakni fungsi mengganti, pendamping, dan pelengkap. Setiap guru bebas memilih menggunakan Edmodo untuk fungsi yang disesuaikan dengan kebutuhan kelasnya

Hasil belajar merupakan kemampuan yang diperoleh individu setelah proses belajar berlangsung, yang dapat memberikan perubahan tingkah laku baik pengetahuan, pemahaman, sikap dan keterampilan siswa sehingga menjadi lebih baik dari sebelumnya. Hasil belajar merupakan salah satu indikator dari proses belajar (Purwanto, 2002).

Berdasarkan hasil observasi dan wawancara dengan guru mata pelajaran IPA di SMPN 02 Sumber Baru ditemukan beberapa permasalahan seperti kurangnya ketertiban siswa dalam proses pembelajaran. Akibatnya siswa menjadi kurang fokus dan kurang tertarik mendengarkan materi yang disampaikan guru. Siswa juga sering ketinggalan materi saat mencatat materi yang disampaikan guru dan konsentrasi siswa pun terbagibagi. Siswa memerlukan bahan ajar yang disampaikan guru di dalam kelas, sedang guru harus mencapai tujuan dari pembelajaran. Untuk meningkatkan kegiatan belajar siswa, dibutuhkan motivasi pembelajaran menggunakan metode Blended Learning agar hasil belajar siswa lebih meningkat lagi (Dharmawati, 2017), proses pembelajaran dengan blended learning akan lebih efektif karena proses peembelajaran yang biasanya dilakukan secara konvensional akan dibantu dengan pembelajaran berbasis Edmodo yang bisa dilakukan kapanpun dan dimanapun, dan Edmodo layak digunakan sebagai media pembelajaran.

Maka dari itu peneliti menerapkan metode blended learning berbasis edmodo, karna metode edmodo dirasa sesuai sebagai pembelajaran efektif terhadap minat dan hasil belajar siswa, Edmodo berpengaruh terhadap ketuntasan belajar pada kategori yang sangat baik (Afdhila, 2017).

\section{METODE PENELITIAN \\ Rancangan Penelitian}

Penelitian ini bertujuan untuk mengetahui peningkatan hasil belajar siswa setelah menggunakan metode blended learning berbasis edmodo materi pencemaran udara kelas VII di SMPN 02 Sumberbaru maka jenis penelitian ini merupakan penelitian tindakan kelas (PTK) karena penelitian di lakukan untuk memecahkan masalah pembelajaran dikelas

\section{Indikator Keberhasilan Dan Siklus}

Indikator keberhasilan tindakan dalam Penelitian Tindakan Kelas ini adalah ditandai dengan adanya peningkatan hasil belajar siswa dengan rata-rata mencapai KKM yaitu 70 dan persentase banyaknya siswa yang tuntas minimum $70 \%$ dengan nilai KKM 70.

\section{Prosedur penelitian}

Penelitian tindakan kelas ini terdiri dari 2 siklus dimana setiap siklus terdiri dari 4 tahap, yaitu perencanaan, tindakan, observasi dan refleksi. 


\section{Metode Pengumpulan Data}

Dalam penelitian ini peneliti menggunakan metode tes, tes yang dimaksud yaitu tes hasil dari siklus I dan siklus II, yang mana siswa diberi soal uraian sebanyak 20 butir pada siklus I dan 20 butir pada siklus II.

\section{Analisis Data}

Dalam penelitian ini analisis data yang digunakan adalah analisis deskriptif kuantitatif terhadap data yang diperoleh dari hasil belajar siswa.

Untuk menghitung rata-rata peningkatan hasil belajar siswa menggunakan rumus:

$$
\mathrm{xi}=\left(\sum \mathrm{x}\right) / \mathrm{n}
$$

Keterangan :

xi = Nilai rata-rata hasil belajar siswa

$\sum \mathrm{x}=$ jumlah seluruh/nilaai siswa

$\mathrm{N}$ = banyak siswa

Sumber : (sudjana,2009)

Untuk menghitung ketuntasan persentase klasikal hasil belajar seluruh siswa menggunakan rumus:

$$
\mathrm{P}=\left(\sum \mathrm{NI}\right) /\left(\sum \mathrm{N}\right)=100 \%
$$

Keterangan :

$\mathrm{P} \quad=$ nilai ketuntasan hasil belajar

$\sum \mathrm{N} 1=$ Jumlah siswa yang tuntas (nilai

$$
\geq 70 \text { ) }
$$

$\sum \mathrm{N}=$ Jumlah total siswa

Sumber: (Kholik,2015).

\section{HASIL DAN PEMBAHASAN}

Penelitian tindakan kelas (PTK) ini mempunyai tujuan untuk mengetahui bagaimana penerapan pembelajaran menggunakan aplikasi edmodo. (Abdurrahman, 1999) menjelaskan bahwa hasil belajar adalah kemampuan yang diperoleh anak setelah melalui kegiatan belajar. Menurutnya juga anak-anak yang berhasil dalam belajar ialah berhasil mencapai tujuan-tujuan pembelajaran atau tujuan instruksional. Data yang diperoleh dari siklus I ke siklus II, pada siklus I terdapat 16 siswa yang nilainya sudah mencapai KKM dan 12 siswa yang masih belum mencapai KKM. Pada siklus II dari 28 siswa ada 24 siswa yang sudah mencapai KKM dan 4 siswa yang masih belum mencapai KKM. Maka dari data tersebut hasil belajar siswa sudah cukup meningkat dengan menggunakan metode blended learning berbasis edmodo.

Perbandingan hasil belajar siswa dengan menggunakan metode blended learning berbasis edmodo pada siklus I dan siklus II dapat dilihat pada grafik berikut.

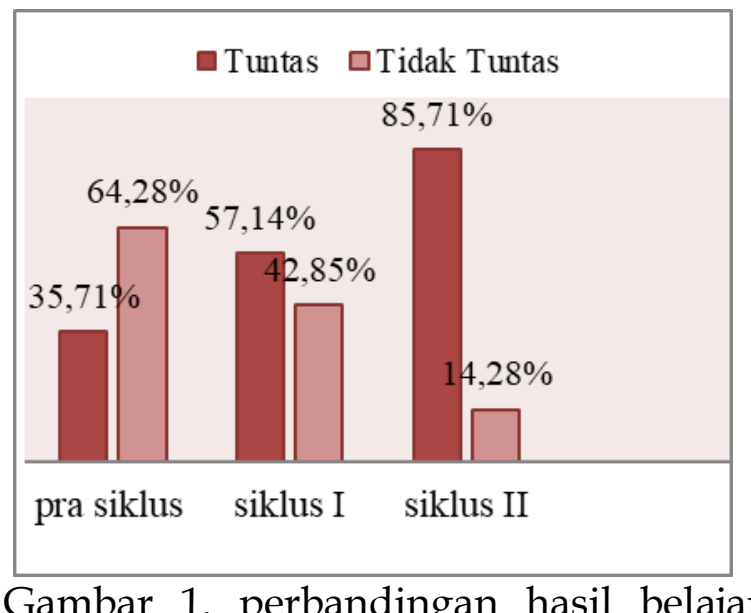

Gambar 1. perbandingan hasil belajar siswa siklus I dan siklus II.

Berdasarkan Gambar 1, data hasil belajar pada prasiklusnya diperoleh persentase 
ketuntasan sebanyak 35,71\%, hal ini dikarenakan guru mata pelajaran IPA masih menggunakan pembelajaran konvensional, sehingga ketika peneliti menerapkan pembelajaran dengan menggunakan metode blended learning berbasis edmodo nilai ketuntasan belajar seluruh siswa pada siklus I mencapai $57,14 \%$ dan disiklus II mencapai 85,71\%. Dengan demikian terdapat peningkatan nilai ketuntasan hasil belajar pada siklus I dan siklus II. Dari hasil tersebut dapat dikatakan bahwa peningkatan hasil belajar sudah mencapai indikator keberhasilan yaitu apabila adanya peningkatan hasil belajar siswa dari siklus I dan siklus II yang mencapai nilai $70 \%$ Maka penggunaan metode blended learning berbasis edmodo sangat tepat untuk membantu proses belajar mengajar. Hal ini sesuai dengan hasil peningkatan siklus I dan siklus II, berdasarkan grafik diatas terlihat terjadi adanya peningkatan hasil belajar siswa sesudah dan sebelumditerapkannya metode blended learning berbasis edmodo pada materi pencemaran udara.

\section{KESIMPULAN}

Berdasarkan hasil penelitian dengan menggunakan metode blended learning berbasis edmodo dapat disimpulkan sebagai berikut.

pembelajaran menggunakan metode blended learning berbasis edmodo dapat meningkatkan hasil belajar siswa, dapat dilihat dari hasil tes yang didapat siswa pra siklus yaitu sebesar 35,71\%, untuk ketuntasan hasil belajar yang didapat di siklus I yaitu sebesar $57,14 \%$, lalu untuk siklus II yang diperoleh sebesar 85,71\%.

\section{DAFTAR PUSTAKA}

Abdurrahman. 1999. Pendidikan Bagi Anak Berkesulitan Belajar. Jakarta: Rineka Cipta

Afdhila, R.; Nazar, M \& Hanum, L. 2017. Penerapan Pembelajaran Blended Learning Pada Materi Larutan Penyangga Di SMAN 1 Unggul Darul Imarah. Jurnal Ilmiah Mahasiswa Pendidikan Kimia, II 93): 165172

Basori. 2013. Pemanfaatan Social Learning Network "Edmodo" dalam Membantu Perkuliahan Teori Bodi Otomotif di Prodi PTM JPTK FKIP UNS. JIPTEK. Vol VI, No. 2. (diakses 15 Desember 2014).

Dharmawati. 2017. Penggunaan media e-learning berbasis edmodo dalam pembelajaran english for bussines. QUERY : jurnal sistem informasi,1(1),43-49,

Dwiyogo, W.D. 2011. Pembelajaran Berbasis Blended Learning. (Online)., diakses tanggal 1 Juni 2013).

Graham, C.R., Allen, S., and Ure, D. 2003. Blended Learning Environments: A Review of The Research Literature, diakses 2 Maret.

Heinze, A., Procter, C \& Scott, B. 2007. Use of Conversation Theory to underpin Blended Learning. International Journal ofTeaching and Case Studies, 1(1), 108-120.

Kholik,Noor. 2015. Penerapan Pembelajaran IPA Dengan Metode SO3R Untuk Meningkatkan Hasil Belajar Siswa Pada Konsep Sistem Eksresi Manusia Di Mts. NU 06 Sunan Abinawa Pengadon Kendal Kelas IX-C 
Sememster Gasal Tahun 2014. Jurnal pendidikan biologi universitas islam negeri walisongo semarang

Nana, Sudjana. 2009. Penilaian Hasil Proses Belajar Mengajar. Bandung :PT. Remaja Rosdakarya

Purwanto. 2004. Prinsip-Prinsip Dan Teknik Evaluasi Pengajaran. Bandung : Rosdakarya

Suriadhi, Gede. 2014. Pengembangan E-learning Berbasis Edmodo pada Mata Pelajaran IPA Kelas VIII di SMPN 2 Singaraja. Journal Edutech. Vol. II No. 1. (Online diakses 15 Desember 2014). 